\title{
Perbandingan Hasil Belajar Dalil Pythagoras Melalui Model Kooperatif Tipe Pair Checks dengan Numbered Heads Together pada Siswa Kelas VIII SMP Negeri 1 Sungguminasa Kabupaten Gowa
}

\author{
Wilda Syam Tonra \\ Universitas Khairun \\ wildaunkhair@gmail.com
}

\begin{abstract}
ABSTRAK
Penelitian eksperimen ini bertujuan untuk mengetahui apakah ada perbedaan hasil belajar siswa pada materi dalil pythagoras yang diajar menggunakan dua model pembelajaran yang berbeda pada dua kelas eksperimen yang berbeda pula. kelas eksperimen I diajar melalui model kooperatif tipe Pair Checks sedangkan kelas eksperimen II diajar melalui model kooperatif tipe Numbered Heads Together. Subjek penelitian adalah siswa kelas VIII SMP Negeri 1 Sungguminasa Kabupaten Gowa. Desain penelitian ini adalah randomized posttest only control group design. Desain ini digunakan dua kelas yang dibentuk secara acak dan diasumsikan memiliki karakteristik yang sama (homogen). Pada kedua kelas diberikan perlakuan yang berbeda sesuai dengan model pembelajaran masing-masing dan akhirnya diberikan posttest (testnya sama). Hasil penelitian menunjukkan bahwa ada perbedaan hasil belajar dalil Pythagoras yang diajar melalui model kooperatif tipe pair checks dengan numbered heads together, namun tidak signifikan. Keduanya pun berada pada kategori yang sama yaitu "tinggi". Sehingga dapat disimpulkan bahwa tidak ada perbedaan hasil belajar dalil Pythagoras yang diajar melalui model kooperatif tipe pair checks dengan numbered heads together.
\end{abstract}

Kata kunci: Penelitian eksperimen; pair checks; numbered heads together; dalil pythagoras

\section{PENDAHULUAN}

Pembelajaran kooperatif adalah salah satu model pembelajaran yang memainkan banyak peranan dalam proses pembelajaran, siswa bekerja sama dalam kelompok kecil saling membantu untuk mempelajari suatu materi (Slavin, 2008). Artzt dan Newman (Trianto, 2010) menyatakan bahwa dalam pembelajaran kooperatif siswa belajar bersama sebagai suatu tim dalam menyelesaikan tugas-tugas kelompok untuk mencapai tujuan bersama. Sehingga, setiap anggota kelompok memiliki tanggung jawab yang sama untuk keberhasilan kelompoknya.

Pembelajaran kooperatif ini memiliki beberapa tipe, dua diantaranya adalah model kooperatif tipe pair checks dengan numbered heads together (NHT). Menurut Ibrahim (Ernawati, 2009) Pair Checks merupakan salah satu cara untuk membantu siswa yang suka mendominasi belajar, keterampilan berbagi adalah meminta mereka bekerja berpasangan dan menerapkan susunan pengecekan berpasangan.

Langkah-langkah Pair Check yaitu bekerja berpasangan, satu siswa dalam pasangan itu mengerjakan lembar kegiatan atau masalah sementara siswa lain membantu atau melatih. Kemudian pelatih mengecek pekerjaan partnernya. Apabila pelatih dan partnernya tidak sependapat terhadap suatu jawaban atau ide, mereka boleh meminta petunjuk dari pasangan lain. Langkah berikutnya, bertukar peran. Seluruh partner bertukar peran dan mengulangi langkah seperti di awal. Pasangan mengecek dan seluruh pasangan tim kembali bersama dan membandingkan jawaban. Terakhir tim menyatakan suka cita kebersamaan apabila seluruhnya setuju dengan jawaban.

Tipe koperatif berikutnya adalah Numbered Heads Together (NHT) merupakan jenis pembelajaran kooperatif yang dirancang untuk mempengaruhi pola interaksi siswa dan sebagai 
alternatif terhadap struktur kelas tradisional. NHT pertama kali dikembangkan oleh Spencer Kagen (Abdul, 2014) untuk melibatkan lebih banyak siswa dalam menelaah materi yang tercakup dalam suatu materi pelajaran dan mengecek pemahaman mereka terhadap isi pelajaran tersebut.

Adapun langkah-langkah model kooperatif tipe NHT yaitu: Penomoran. Guru membagi siswa menjadi beberapa kelompok heterogen yang beranggotakan 4 sampai 5 orang dan memberi nomor untuk setiap anggota kelompok, sehingga setiap siswa dalam kelompok memiliki nomor yang berbeda-beda. Mengajukan Pertanyaan. Pada tahap ini, guru mengajukan pertanyaan kepada siswa. Pertanyaan dapat bervariasi dari yang spesifik hingga bersifat umum dan memiliki tingkat kesulitan yang berbeda. Berpikir Bersama. Siswa berpikir bersama untuk menemukan jawaban dan menjelaskan jawaban kepada anggota kelompoknya sehingga semua anggota kelompok mengetahui jawaban dari masing-masing pertanyaan. Langkah terakhir yaitu guru menyebut salah satu nomor dan setiap siswa dari tiap kelompok yang bernomor sama mengangkat tangan dan menyiapkan jawaban untuk dipresentasikan di depan kelas, Kelompok lain yang bernomor sama merespon jawaban tersebut

Beberapa penelitian relevan dengan penelitian ini adalah hasil penelitian oleh Aspriyani, Mardiyana, Saputro (2014) terkait perbandingan NHT dan think pair share (TPS) menyatakan bahwa siswa yang dikenai model pembelajaran NHT mempunyai prestasi belajar sama baiknya dengan siswa yang dikenai model pembelajaran TPS, tetapi lebih baik dari pada siswa yang dikenai model pembelajaran Konvensional. Penelitian lain oleh Sari, Herkulana, Rosyid (2015) menunjukkan bahwa penerapan model pembelajaran Pair Checks efektif dibandingkan model pembelajaran konvensional dalam meningkatkan keterampilan siswa. Penelitian berikutnya oleh Megawati (2016) menunjukkan bahwa hasil belajar matematika siswa setelah di ajar dengan menggunakan model kooperatif tipe Jigsaw dan NHT dikategorikan sedang sehingga disimpulkan hasil belajar matematika siswa dengan menggunakan model kooperatif tipe Jigsaw tidak jauh lebih efektif dari pada model kooperatif tipe NHT. Dari hasil penelitian di atas dan penelitian lainnya, terdapat perbedaan penelitian saat ini dengan penelitian yang telah dilaksanakan karena belum ada yang membandingkan NHT dan Pair Check.

\section{METODE}

Jenis Penelitian adalah penelitian eksperimen yang melibatkan dua kelompok, yaitu kelas eksperimen I dan kelas eksperimen II. kelas eksperimen I diajar melalui model kooperatif tipe Pair Checks sedangkan kelas eksperimen II diajar melalui model kooperatif tipe NHT. Variabel penelitian ini adalah hasil belajar tentang dalil pythagoras yang dicapai oleh siswa kelas VIII SMP Negeri 1 Sungguminasa Kabupaten Gowa. Desain penelitian ini adalah randomized posttest only control group design. Desain ini digunakan dua kelas yang dibentuk secara acak dan diasumsikan memiliki karakteristik yang sama (homogen). Pada kedua kelas diberikan perlakuan yang berbeda dan akhirnya diberikan posttest (testnya sama).

Adapun model desainnya adalah :

\begin{tabular}{ccc}
\hline Kelompok & Variabel & Posttest \\
\hline $\mathrm{R}_{1}$ & $\mathrm{X}_{1}$ & $\mathrm{Y}_{1}$ \\
\hline $\mathrm{R}_{2}$ & $\mathrm{X}_{2}$ & $\mathrm{Y}_{1}$ \\
\hline \multicolumn{3}{c}{ (Sukardi, 2003) }
\end{tabular}

Keterangan :

$\mathrm{R}_{1}$ : kelas eksperimen I

$\mathrm{R}_{2}$ : kelas eksperimen II

$\mathrm{X}_{1}$ : perlakuan pertama pair checks

$\mathrm{X}_{2}$ : perlakuan kedua NHT

$\mathrm{Y}_{1}$ : posttest

Teknik pengambilan sampel yang digunakan dalam penelitian ini adalah cluster sampling, yaitu dengan memilih dua kelas dari sembilan kelas (populasi) yang homogen. Dari proses tersebut, terpilihlah kelas VIII $_{A}$ dan kelas VIII $_{B}$ kemudian dari dua kelas tersebut, dilakukan pemilihan kembali dengan cara random sampling yaitu undian. Sehingga terpilihlah kelas VIII $_{\mathrm{A}}$ sebagai kelas eksperimen I yang diajar dengan menggunakan pembelajaran kooperatif tipe Pair Checks dan secara otomatis kelas VIII $_{\mathrm{B}}$ 
sebagai kelas eksperimen II yang diajar dengan menggunakan pembelajaran kooperatif tipe NHT.

Teknik Analisis Data yaitu analisis Statistika Deskriptif adalah analisis yang menggambarkan karateristik hasil belajar siswa yang meliputi: nilai tertinggi, nilai terendah, rentang nilai, nilai rata-rata dan yang lainnya dan analisis Statistika Inferensial untuk menguji hipotesis penelitian dengan menggunakan uji-t. Namun sebelum dilakukan pengujian hipotesis, terlebih dahulu dilakukan uji normalitas dan homogenitas.

\section{HASIL DAN PEMBAHASAN}

\section{Hasil analisis statistika deskriptif}

Hasil belajar dalil Pythagoras melalui model kooperatif tipe pair checks.

Hasil analisis statistika deskriptif diperoleh rangkuman nilai stastistika hasil belajar dalil Pythagoras siswa kelas $\mathrm{VIII}_{\mathrm{A}}$ SMP Negeri 1 Sungguminasa Kabupaten Gowa yang diajar dengan menggunakan model kooperatif tipe pair checks ditunjukkan pada tabel.

Tabel 1. Hasil analisis statistika deskriptif $\mathrm{VIII}_{\mathrm{A}} \mathrm{SMP}$ Negeri 1 Sungguminasa Kabupaten Gowa yang diajar dengan menggunakan model kooperatif tipe pair

\begin{tabular}{cc}
\multicolumn{2}{c}{ checks. } \\
\hline Statistika & Nilai Statistika \\
\hline Ukuran sampel & 36 \\
Nilai tertinggi & 100 \\
Nilai terendah & 70 \\
Rentang nilai & 30 \\
Nilai rata-rata & 83,92 \\
Variansi & 85,450 \\
Standar deviasi & 9,244 \\
\hline
\end{tabular}

Jika keseluruhan nilai yang diperoleh siswa dikelompokkan dalam lima kategori, maka distribusi frekuensi dan persentase hasil belajar

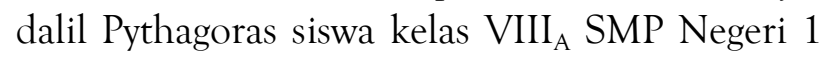
Sungguminasa Kabupaten Gowa, yang diajar dengan menggunakan model kooperatif tipe pair checks ditunjukkan pada tabel.

Tabel 2. Distribusi frekuensi dan persentase hasil

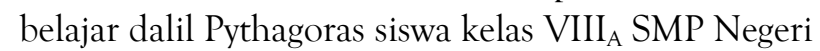

1 Sungguminasa Kabupaten Gowa, yang diajar dengan model kooperatif tipe pair checks.

\begin{tabular}{cccc}
\hline Skor & Kategori & Frek & Persentase (\%) \\
\hline $90-100$ & Sangat tinggi & 14 & $38,88 \%$ \\
$80-89$ & Tinggi & 11 & $30,56 \%$ \\
\hline
\end{tabular}

\begin{tabular}{cccc}
\hline $65-79$ & Sedang & 11 & $30,56 \%$ \\
$55-64$ & Rendah & - & - \\
$0-54$ & Sangat rendah & - & - \\
\hline
\end{tabular}

Berdasarkan tabel 1. dan 2. diperoleh skor rata-rata hasil belajar dalil Pythagoras siswa kelas VIII $_{\mathrm{A}}$ SMP Negeri 1 Sungguminasa Kabupaten Gowa yang diajar dengan menggunakan model kooperatif tipe pair checks adalah 83,92 dengan standar deviasi 9,244. Jika hal ini dikaitkan pada tabel distribusi frekuensi dan persentase nilai hasil belajar dalil Pythagoras siswa kelas VIII $_{\mathrm{A}}$ SMP Negeri 1 Sungguminasa Kabupaten Gowa yang diajar melalui model kooperatif tipe pair checks dikategorikan "tinggi".

Hasil belajar dalil Pythagoras melalui model kooperatif tipe $N H T$

Hasil analisis statistika deskriptif diperoleh rangkuman nilai stastistika hasil belajar dalil Pythagoras siswa kelas VIII $_{B}$ SMP Negeri 1 Sungguminasa Kabupaten Gowa yang diajar dengan menggunakan model kooperatif tipe NHTditunjukkan pada tabel.

Tabel 3. Hasil analisis statistika deskriptif VIII ${ }_{\mathrm{B}}$ SMP Negeri 1 Sungguminasa Kabupaten Gowa yang diajar dengan menggunakan model kooperatif tipe NHT

\begin{tabular}{cc}
\hline Statistika & Nilai Statistika \\
\hline Ukuran sampel & 36 \\
Nilai tertinggi & 100 \\
Nilai terendah & 60 \\
Rentang nilai & 40 \\
Nilai rata-rata & 80,83 \\
Variansi & 146,200 \\
Standar deviasi & 12,091 \\
\hline
\end{tabular}

Jika keseluruhan nilai yang diperoleh siswa dikelompokkan dalam lima kategori, maka distribusi frekuensi dan persentase hasil belajar

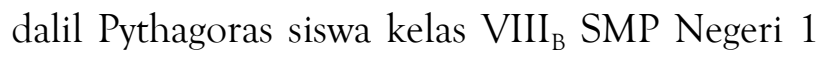
Sungguminasa Kabupaten Gowa, yang diajar dengan menggunakan model kooperatif tipe NHT ditunjukkan pada tabel.

Tabel 4. Distribusi frekuensi dan persentase hasil belajar dalil Pythagoras siswa kelas $\mathrm{VIII}_{B} \mathrm{SMP}_{\mathrm{N}}$ Negeri

1 Sungguminasa kabupaten Gowa, yang diajar dengan model kooperatif tipe NHT

\begin{tabular}{cccc}
\hline Skor & Kategori & Frek & Persentase (\%) \\
\hline $90-100$ & Sangat tinggi & 11 & $30,56 \%$ \\
$80-89$ & Tinggi & 11 & $30,56 \%$ \\
$65-79$ & Sedang & 11 & $30,56 \%$ \\
$55-64$ & Rendah & 3 & $8,32 \%$ \\
$0-54$ & Sangat rendah & - & - \\
\hline
\end{tabular}


Berdasarkan tabel 3. dan 4. diperoleh skor rata-rata hasil belajar dalil Pythagoras siswa kelas VIII $_{\text {B }}$ SMP Negeri 1 Sungguminasa Kabupaten Gowa yang diajar dengan menggunakan model kooperatif tipe NHT adalah 80,83 dengan standar deviasi 12,091. Jika hal ini dikaitkan pada tabel distribusi frekuensi dan persentase nilai hasil belajar dalil Pythagoras siswa kelas VIII $_{B}$ SMP Negeri 1 Sungguminasa yang diajar melalui model kooperatif tipe NHT dikategorikan "tinggi".

\section{Hasil Analisis statistika inferensial}

Sesuai dengan hipotesis penelitan, maka teknik yang digunakan untuk menguji hipotesis tersebut adalah teknik statistika $t$ (uji-t). Namun sebelum membahas statistika $t$, terlebih dahulu dilakukan persyaratan analisis yaitu uji normalitas dan uji homogenitas.

\section{Uji Normalitas}

Pengujian normalitas bertujuan untuk mengetahui apakah rata-rata hasil belajar siswa berasal dari populasi berdistribusi normal. Berdasarkan lampiran tersebut, dari analisis data secara inferensial diperoleh nilai $\mathrm{p}=0,085$ yang lebih besar dari nilai $u=0,05$, ini berarti bahwa kedua kelompok berasal dari data yang berdistribusi normal.

\section{Uji Homogenitas}

Berdasarkan hasil pengujian homogenitas dengan levene's test for equalitas of variances pada lampiran, diperoleh nilai $\mathrm{p}=0,286$ yang lebih besar dari nilai $u=0,05$ yang berarti bahwa data dalam penelitian ini memiliki variansi homogen.

\section{Uji hipotesis}

Berdasarkan hasil pengujian normalitas dan homogenitas diperoleh bahwa data penelitian berdistribusi normal dan memiliki variansi yang homogen, selanjutnya dilakukan pengujian terhadap hipotesis dengan menggunakan statistika inferensial yaitu statistika uji-t. Teknik analisis statistika menggunakan pengolahan data SPSS versi 15,0 for windows. Digunakan independent sample $t$ test dengan kriteria pengujian hipotesis $\mathrm{H}_{0}$ ditolak atau $\mathrm{H}_{1}$ diterima jika $\mathrm{P}<u$, artinya ada perbedaan antara kedua perlakuan yang diberikan. Sebaliknya $\mathrm{H}_{0}$ diterima atau $\mathrm{H}_{1}$ ditolak jika $\mathrm{P}>\boldsymbol{u}$, artinya tidak ada perbedaan antara kedua perlakuan yang diberikan.
Hasil analisis diperoleh $t=0,228$. Ini berarti bahwa $\mathrm{P}>u$, maka $\mathrm{H}_{0}$ diterima atau menolak $\mathrm{H}_{1}$ sehingga dapat disimpulkan bahwa walaupun ada perbedaan hasil belajar siswa, namun karena tidak signifikan dan keduanya berada pada kategori yang sama yaitu "tinggi" bahwa tidak ada perbedaan hasil belajar dalil Pythagoras yang diajar melalui model kooperatif tipe pair checks dengan numbered heads together

\section{KESIMPULAN}

Berdasarkan hasil penelitian yang telah diuraikan di atas, maka secara deskriptif, hasil belajar dalil Pythagoras siswa kelas VIII SMP negeri 1 Sungguminasa Kabupaten Gowa yang menggunakan pembelajaran kooperatif tipe pair checks memperoleh skor rata-rata 83,92 berada pada interval 80-89 yang dikategorikan tinggi, dengan standar deviasi 9,244 sedangkan yang menggunakan pembelajaran kooperatif tipe numbered heads together memperoleh skor rata-rata 80,83 berada pada interval 80-89 yang dikategorikan tinggi, dengan standar deviasi 12,091.

Hasil tersebut diperkuat oleh hasil analisis statistika inferensial yang menunjukkan bahwa walaupun ada perbedaan hasil belajar siswa, namun karena tidak signifikan dan keduanya berada pada kategori yang sama yaitu "tinggi" bahwa tidak ada perbedaan hasil belajar dalil Pythagoras yang diajar melalui model kooperatif tipe pair checks dengan NHT.

Di dalam penerapannya di kelas, model pembelajaran kooperatif tipe pair checks, siswa yang bekerja secara berpasangan mampu menyelesaikan tugas yang diberikan dengan baik, aktif, mampu bekerja sama secara kooperatif, tidak mengganggu pasangan lainnya, dan tepat waktu dalam bekerja. Hal ini tentunya berdampak positif bagi hasil belajar siswa, yang dapat terlihat dari hasil belajar dalil Pythagoras yang dikategorikan tinggi. Sedangkan model pembelajaran kooperatif tipe NHT, siswa yang bekerja secara berkelompok yang terdiri dari 4 orang, juga mampu menyelesaikan tugas dengan baik, aktif, mampu bekerja sama dengan baik, namun karena dalam satu kelompok NHT terdiri dari 4 orang, siswa membutuhkan waktu 
yang lebih banyak untuk menyatukan pendapat dan berdiskusi dibandingkan dengan pair checks. Sehingga terkadang waktu tidak mencukupi pada saat pelaksanaannya di kelas.

\section{DAFTAR PUSTAKA}

Abdul. M. 2014. Strategi Pembelajaran. PT Remaja Rosdakarya. Bandung.

Aspriyani, R., Mardiyana., Sari. D.R, 2014. Eksperimentasi Pembelajaran Matematika Dengan Model Kooperatif Tipe Numbered Head Together (NHT) Dan Think Pair Share (TPS) Terhadap Prestasi Belajar Dan Motivasi Berprestasi Siswa Ditinjau Dari Kecerdasan Emosional Pokok Materi Persamaan Linear Satu Variabel (PLSV) Pada Siswa SMPN Di Kota Surakarta. Jurnal Elektronik Pembelajaran Matematika.

Ernawati. 2009. Meningkatkan Hasil Belajar Matematika Melalui Pembelajaran Kooperatif Tipe Pair Checks Pada Siswa Kelas VII SMP Guppi Samata Kabupaten Gowa. Skripsi Fakultas Keguruan dan Ilmu Pendidikan. Universitas Muhammadiyah Makassar.

Megawati. 2016. Perbandingan Hasil Belajar

Matematika Melalui Penerapan Model Pembelajaran Kooperatif Tipe Jigsaw dan Tipe Numbered Head Together (NHT) Di SMA Negeri 1 Walenrang. Prosiding Seminar Nasional Volume 03, Nomor 1. ISSN 2443. 1109

Sukardi. 2003. Metodologi Penelitian Pendidikan.Yogyakarta : Bumi Aksara

Slavin, E. Robert. 2008. Cooperative Learning Teori Riset dan Praktik. Bandung ; Nusa Media.

Sari, G.P., Herkulana, Rosyid, R. 2015. Efektivitas Model Pembelajaran Pair Checks Terhadap Keterampilan Siswa pada Mata Pelajaran Akuntansi Di SMKN. Jurnal Pendidikan dan Pembelajaran Vol 4, No 9 (2015)

Trianto. 2010. Mendesain Model Pembelajaran Inovatif-Progresif. Jakarta : Kencana 